\title{
Influence of Intravenous Immunoglobulin Treatment on Thrombopoiesis
}

\author{
Oliver Meyer ${ }^{\mathrm{a}} \quad$ Oliver Winter $^{\mathrm{b}} \quad$ Abdulgabar Salama $^{\mathrm{a}}$ \\ a Institut für Transfusionsmedizin, \\ ${ }^{\mathrm{b}}$ Klinik für Neonatologie, Charité - Universitätsmedizin Berlin, Germany
}

\section{Keywords}

IVIg · Thrombopoiesis · IL-6 · Thrombopoietin · ITP

\section{Summary}

Aim: The mechanisms by which intravenous immunoglobulins (IVIg) result in an increase in platelet counts in most patients with autoimmune thrombocytopenia (ITP) have not yet been fully explained. One of these mechanisms may be related to stimulation of thrombopoiesis. Methods: A total of 13 adult patients who received IVIg were studied: 11 patients with primary ITP, 1 patient with ITP related to common variable immunodeficiency (CVID), and 1 patient with uncharacterized thrombocytopenia. IVIg (0.5-1.5 g/kg body weight) was administered on consecutive days (days 1-3). Endogenous thrombopoietin (eTPO) was measured prior to and at least 1 day following treatment. In addition, IL- 6 was measured in 5 of the treated patients. Results: In 10 of 13 patients, IVIg treatment resulted in an increase in platelet counts. ETPO remained unchanged or elevated in almost all cases where the platelet count remained low $\left(<100 \times 10^{3} / \mu \mathrm{l}\right)$. In all cases with normal or increased platelet counts $\left(>100 \times 10^{3} / \mathrm{ul}\right)$, the eTPO concentration decreased. Furthermore, IVIg induced IL-6 synthesis in all 5 examined patients. Conclusion: Our data indicate that the induction of eTPO synthesis by IL- 6 may be a potential mechanism in which IVIg may stimulate thrombopoiesis. Further studies are required to characterize this mechanism.

\section{Schlüsselwörter}

IVIg · Thrombopoese · IL-6 · Thrombopoetin · ITP

\section{Zusammenfassung}

Hintergrund: Der Wirkungsmechanismus hochdosierter intravenöser Immunglobuline (IVIg), bei der Therapie der Autoimmunthrombozytopenie (ITP) ist bisher nicht vollständig bekannt. Eine mögliche Ursache des Thrombozytenanstiegs könnte eine Stimulation der Thrombopoese durch IVIg sein. Methoden: Insgesamt wurden die Verläufe von 13 Patienten, die mit IVlg behandelt wurden ausgewertet. Elf Patienten litten an einer primären ITP, 1 Patient hatte eine sekundäre ITP im Rahmen einer Common-Variable-Immundefizienz (CVID), und 1 weiterer Patient hatte eine Thrombozytopenie unklarer Genese. Die Patienten wurden an 1-3 aufeinanderfolgenden Tagen mit IVlg (0,5-1,5 g/kg Körpergewicht) behandelt. Das endogene Thrombopoetin (eTPO) wurde vor Beginn der Behandlung und mindestens 1 Tag nach Behandlung gemessen. Darüber hinaus wurde bei 5 Patienten die IL6-Konzentration bestimmt. Ergebnisse: Bei 10 der $13 \mathrm{~Pa}$ tienten stieg die Thrombozytenzahl nach Behandlung mit IVIg an. Bei allen Patienten, bei denen die Thrombozytenzahl unter $100 \times 10^{3} / \mu$ l blieb, war das eTPO unverändert oder erhöht. Im Gegensatz dazu war eine Verminderung des eTPO bei den Patienten zu beobachten, bei denen die Thrombozyten über $100 \times 10^{3} / \mu \mathrm{l}$ anstiegen. Bei allen 5 Patienten, bei denen die IL-6-Konzentration gemessen wurde, konnte auch ein IL-6-Anstieg nach IVIgGabe beobachtet werden. Schlussfolgerung: Die hier vorgestellten Daten legen den Schluss nahe, dass die Behandlung mit IVIg zu einer Induktion der IL-6-Synthese und damit zu einer Stimulation der Thrombopoese führt. Allerdings sind weitere Untersuchungen nötig, um diesen Mechanismus näher zu charakterisieren.

\section{KARGER \\ Fax +497614520714 \\ Information@Karger.de}

www.karger.com
(C) 2012 S. Karger GmbH, Freibur

$1660-3796 / 12 / 0393-0217 \$ 38.00 / 0$

Accessible online at:

www.karger.com/tmh
Prof. Dr. Abulgabar Salama

Institut für Transfusionsmedizin

Charité - Universitätsmedizin Berlin

Augustenburger Platz 1, 13353 Berlin, Germany

Tel. +49 30450 553-012, Fax -932

abdulgabar.salama@charite-de 


\section{Introduction}

Chronic autoimmune thrombocytopenia (ITP) is presumably the best characterized autoimmune disease. Nonetheless, there remains much speculation regarding the pathomechanism and mechanisms of treatment concerning this disorder. In addition to autoantibody-mediated platelet destruction, dysfunctional immune regulation, T-cell-mediated platelet destruction, and an impaired platelet production appear to play a role in ITP [1].

Endogenous TPO (eTPO), the primary regulator of platelet production, is primarily secreted from the liver and has no storage form. Once eTPO binds to platelets and to a lesser degree megakaryocytes, it is internalized and removed from the circulation [2-4]. Thus, the eTPO level is inversely proportional to the total amount of circulating platelets. Nevertheless, in ITP patients it has been demonstrated that the level of eTPO is normal or slightly, not highly, increased [5]. This might be related to the fact that increased platelet destruction in ITP leads to a depletion of both platelets and plateletbound eTPO. The administration of recombinant TPO (rTPO) or its receptor agonists increase platelet counts in about $80 \%$ of ITP patients [6,7]. Furthermore, treatment with high-dose intravenous immunoglobulin (IVIg) abruptly elevates platelet counts in approximately $80 \%$ of ITP patients [8]. This effect is gained by multiple mechanisms which include the blockade of Fc receptor-mediated phagocytosis, inhibition of the complement cascade, neutralization of autoantibodies as well as modulation of inhibitory Fc receptor expression and cytokine production [9-11]. As IVIg administration induces the production of IL-6 $[12,13]$ which is known to stimulate eTPO synthesis in hepatocytes [14], we questioned whether IVIg treatment would not only modulate the immune response in ITP but also stimulate the production of platelets via the IL-6-eTPO route.

In order to answer this question, we measured eTPO levels in 13 unselected patients. In addition, IL-6 levels were evaluated in 5 patients prior to and following IVIg treatment.

\section{Patients and Methods}

13 unselected outpatients managed at the Charité Medical School were studied. All patients required treatment with IVIg. 11 patients (no. 1-7, 9-12) had ITP and required emergency treatment due to bleeding complications, 1 patient (no. 13) had ITP related to common variable immunodeficiency (CVID), and 1 patient (no. 8) had an unclear thrombocytopenia, initially misdiagnosed as ITP. Peripheral blood samples for measuring the platelet count, eTPO, and IL-6 were collected directly prior to and following treatment with IVIg, which was administered in doses of 0.5-1.5 $\mathrm{g} / \mathrm{kg} \mathrm{BW}$ over 3 consecutive days.

eTPO and IL-6 were measured using commercially available ELISA Kits (R\&D Systems, Wiesbaden-Nordenstadt, Germany, and BioLegend $\mathrm{GmbH}$, Fell, Germany, respectively), according to the manufacturer's instructions.

\section{Results}

Following IVIg treatment, platelet counts increased to a variable degree in 10 cases (no. 1-4, 6, 7, 9-11, and 13) and remained primarily unaltered in 3 patients (no. 5, 8, and 12). In 6 patients, the concentration of free eTPO decreased with increasing platelet counts (no. 3, 4, 6, 7, 9, 11). However, in 1 patient (no. 2), both the platelet count and eTPO concentration increased, and in another patient (no. 13), the eTPO concentration remained widely unchanged even though the platelet count increased. The eTPO remained undetectable in 1 patient with normal baseline platelet counts. In those patients who did not respond to IVIg treatment, the eTPO concentration remained either constant (no. 5) or increased (no. 8, 12). Free eTPO was undetectable in patients with platelet counts $\geq 100 \times 10^{3} / \mu \mathrm{l}$ (no. 4, 7, 9, and 13) and unchanged or elevated in patients with platelet counts below $100 \times 10^{3} / \mu l$ (no. $1,2,5$, 8 , and 12).

IVIg administration resulted in an increase in IL-6 levels in all 5 patients analyzed (no. 9-13). In 2 patients who responded to IVIg, the IL-6 concentration increased with decreasing eTPO concentrations (no. 9 and 11). In 2 patients, IVIg resulted in no or only a minor increase in platelet counts (no. 10 and 12). The eTPO concentration decreased in patient no. 10 and increased in patient no. 12. Patient no. 13 presented normal platelet counts prior to IVIg administration. However, the platelet count in this patient increased with increasing IL-6 concentrations although the eTPO concentration remained unaltered (table 1).

\section{Discussion}

The results in this study indicate that IVIg treatment influences eTPO levels, particularly in cases where platelet counts remained below $100 \times 10^{3} / \mu 1$ (no. 2 and 8 ). To further characterize this phenomenon, eTPO and IL-6 levels were measured in an additional group of 5 patients who required IVIg treatment. Once again, eTPO increased in 2 patients (no. 9 and 12), whereas IL-6 increased in all 5 analyzed patients. Furthermore, IVIg led also to an increase of IL-6 and of the platelet count in 1 patient with normal platelet count. This finding supports the results obtained in previous studies $[12,13]$ and indicates that the increase in eTPO may be explained by the increase in IL-6, which has previously been demonstrated to stimulate thrombopoiesis [14, 15]. The question why IVIg and IL-6 did not invariably demonstrate an increase in eTPO might be explained by the regulatory mechanism of eTPO and platelet rate. eTPO is primarily secreted from the liver, has no storage form, and enters the circulation. Once eTPO binds to platelets, and to a lesser degree megakaryocytes, it is internalized and removed from the circulation [2-4]. Thus, the level of eTPO is dependent on the total amount of circulating platelets. When platelet 
Table 1. Patient characteristics and study data

\begin{tabular}{|c|c|c|c|c|c|c|c|}
\hline Patient no. & Sex/age & Diagnosis & Day & Platelets $\times 10^{3} / \mu \mathrm{l}$ & IVIg, g/kg BW & eTPO, pg/ml & IL-6, pg/ml \\
\hline \multirow[t]{2}{*}{1} & $\mathrm{f} / 74$ & ITP & 0 & 33 & 1.0 & 32 & \\
\hline & $\mathrm{f} / 74$ & ITP & 14 & 75 & & 36 & \\
\hline \multirow[t]{2}{*}{2} & $\mathrm{f} / 42$ & ITP & 0 & 10 & 1.0 & 122 & \\
\hline & & & 3 & 45 & & 340 & \\
\hline \multirow[t]{2}{*}{3} & $f / 36$ & ITP & 0 & 30 & 1.0 & 41.8 & \\
\hline & & & 4 & 112 & & 8 & \\
\hline \multirow[t]{2}{*}{4} & $\mathrm{~m} / 50$ & ITP & 0 & 10 & 1.5 & 190 & \\
\hline & & & 3 & 124 & & n.d & \\
\hline \multirow[t]{2}{*}{5} & $\mathrm{f} / 51$ & ITP & 0 & 10 & 1.5 & 190 & \\
\hline & & & $?$ & 15 & & 181 & \\
\hline \multirow[t]{3}{*}{6} & $\mathrm{~m} / 69$ & ITP & 0 & 10 & 1.0 & 9.8 & \\
\hline & & & 2 & 72 & & 73 & \\
\hline & & & 4 & 103 & & n.d. & \\
\hline \multirow[t]{4}{*}{7} & $\mathrm{~m} / 58$ & ITP & 0 & $<10$ & 0.8 & 41.1 & \\
\hline & & & 5 & 375 & & n.d. & \\
\hline & & & 9 & 399 & & n.d. & \\
\hline & & & 19 & 67 & & 44.5 & \\
\hline \multirow[t]{3}{*}{8} & $\mathrm{f} / 40$ & $\mathrm{TP}$ & 0 & 0 & 0.8 & 31 & \\
\hline & & & 9 & $<10$ & & 79.4 & \\
\hline & & & 15 & $<10$ & & 75.3 & \\
\hline \multirow[t]{3}{*}{9} & $\mathrm{f} / 40$ & ITP & 0 & 53 & 0.8 & 15.5 & n.d. \\
\hline & & & 1 & 91 & 0.8 & 19.5 & n.d. \\
\hline & & & 2 & 150 & & n.d. & 6.4 \\
\hline \multirow[t]{3}{*}{10} & $\mathrm{f} / 53$ & ITP & 0 & $<10$ & 0.8 & 194 & n.d. \\
\hline & & & 1 & $<10$ & 0.8 & 141 & n.d. \\
\hline & & & 2 & 26 & & 108 & 16.4 \\
\hline \multirow[t]{4}{*}{11} & $\mathrm{f} / 62$ & ITP & 0 & 15 & 0.5 & 77.2 & n.d. \\
\hline & & & 3 & 27 & 0.5 & 24.0 & n.d. \\
\hline & & & 4 & 32 & 0.5 & 19.2 & 9.9 \\
\hline & & & 5 & 39 & & 16.5 & 28.9 \\
\hline \multirow[t]{2}{*}{12} & $f / 37$ & ITP & 0 & $<10$ & 0.8 & 10.6 & n.d. \\
\hline & & & 1 & $<10$ & & 35.5 & 0.61 \\
\hline \multirow[t]{3}{*}{13} & $f / 33$ & ITP/CVID & 0 & 175 & 0.8 & n.d. & n.d. \\
\hline & & & 1 & 195 & & n.d. & 10.6 \\
\hline & & & 2 & 212 & & n.d. & 12.6 \\
\hline
\end{tabular}

production is reduced, eTPO clearance is also decreased, resulting in its increase in plasma, eventually stimulating thrombopoiesis. Unfortunately, we did not measure eTPO levels at different times following IVIg administration in order to determine the peaks of change during our observation. Suggesting that the peak level of IL- 6 occurs within $1 \mathrm{~h}$ following IVIg administration $[12,13]$ and that of eTPO at least within or after 2 days following an increase in IL-6 [14], we were unable to record all significant changes in either IL-6 or eTPO. This point should be more precisely considered in future studies, though the true effect of IVIg or IL-6 on eTPO may, at least in part, remain obscure due to the aforementioned regulatory mechanism. Whether IVIg may also stimulate thrombopoiesis by other mechanisms remains speculative. Whatever the mechanisms may be, there remains no doubt that IVIg, to some extent, stimulates thrombopoiesis. During the course of this study, a similar conclusion has recently been drawn by other authors who demonstrated an increase in the absolute immature platelet fraction in 2 of 6 ITP patients following IVIg administration [16]. In addition, these authors cited data of 2 other patients who were treated with IVIg and in whom platelet counts were observed to increase although platelet survival was not adequately enhanced [17]. Since IVIg operates in vivo via sev- 
eral mechanisms [11], it remains unclear whether the effect related to thrombopoiesis invariably occurs and whether the total dose may also play a role. Further studies are required not only to determine optimal IVIg doses to achieve this effect but also to clarify whether this effect occurs in all patients.

\section{Acknowledgement}

O.M. treated the patients, planned the study, analyzed the data and wrote the manuscript; O.W. planned the study, performed the TPO and IL-6 measurements, analyzed the data, and wrote the manuscript; A.S. planned the study, analyzed the data, and wrote the manuscript.

We thank Dr. Sundrela Kamhieh-Milz for editing and drafting the manuscript.

\section{Disclosure Statement}

A.S. and O.M. conduct clinical studies on behalf of Amgen, GlaxoSmithKline, Octapharma, LMB, and Biotest. A.S. received consultation fees from Amgen, GlaxoSmithKline, Octapharma, LMB, and Biotest. O.M. received consultation fees from Amgen and GlaxoSmithKline. O.W. declares no conflict of interest.

\section{References}

$>_{1}$ Cines DB, Bussel JB, Liebman HA, Luning Prak ET: The ITP syndrome: pathogenic and clinical diversity. Blood 2009;113:6511-6521.

2 Broudy VC, Lin NL, Sabath DF, Papayannopoulou T, Kaushansky K: Human platelets display highaffinity receptors for thrombopoietin. Blood 1997;89:1896-1904.

3 Kuter DJ, Begley CG: Recombinant human thrombopoietin: basic biology and evaluation of clinical studies. Blood 2002;100:3457-3469.

4 Li J, Xia Y, Kuter DJ: Interaction of thrombopoietin with the platelet c-mpl receptor in plasma: binding, internalization, stability and pharmacokinetics. BrJ Haematol 1999;106:345-356.

5 Stasi R, Evangelista ML, Amadori S: Novel thrombopoietic agents: a review of their use in idiopathic thrombocytopenic purpura. Drugs 2008;68:901-912.

6 Kuter DJ: Thrombopoietin and thrombopoietin mimetics in the treatment of thrombocytopenia Annu Rev Med 2009;60:193-206.

7 Stasi R, Bosworth J, Rhodes E, Shannon MS, Willis F, Gordon-Smith EC: Thrombopoietic agents. Blood Rev;24:179-190.
8 Godeau B, Caulier MT, Decuypere L, Rose C, Schaeffer A, Bierling P: Intravenous immunoglobulin for adults with autoimmune thrombocytopenic purpura: results of a randomized trial comparing 0.5 and $1 \mathrm{~g} / \mathrm{kg}$ b.w. Br J Haematol 1999;107:716-719.

9 Sewell WA, Jolles S: Immunomodulatory action of intravenous immunoglobulin. Immunology 2002; 107:387-393.

10 Nimmerjahn F, Ravetch JV: Anti-inflammatory actions of intravenous immunoglobulin. Annu Rev Immunol 2008;26:513-533.

11 Imbach P, Lazarus AH, Kuhne T: Intravenous immunoglobulins induce potentially synergistic immunomodulations in autoimmune disorders. Vox Sang 2010;98:385-394.

12 Aukrust P, Froland SS, Liabakk NB, Muller F, Nordoy I, Haug C, Espevik T: Release of cytokines, soluble cytokine receptors, and interleukin-1 receptor antagonist after intravenous immunoglobulin administration in vivo. Blood 1994;84:2136-2143.

13 Ling ZD, Yeoh E, Webb BT, Farrell K, Doucette J, Matheson DS: Intravenous immunoglobulin induces interferon-gamma and interleukin-6 in vivo. J Clin Immunol 1993;13:302-309.
14 Kaser A, Brandacher G, Steurer W, Kaser S, Offner FA, Zoller H, Theurl I, Widder W, Molnar C, Ludwiczek O, Atkins MB, Mier JW, Tilg H: Interleukin-6 stimulates thrombopoiesis through thrombopoietin: role in inflammatory thrombocytosis. Blood 2001;98:2720-2725.

15 Kaushansky K: The molecular mechanisms that control thrombopoiesis. J Clin Invest 2005;115: 3339-3347.

16 Barsam SJ, Psaila B, Forestier M, Page LK, Sloane PA, Geyer JT, Villarica GO, Ruisi MM, Gernsheimer TB, Beer JH, Bussel JB: Platelet production and platelet destruction: assessing mechanisms of treatment effect in immune thrombocytopenia. Blood 2011;117:5723-5732.

17 Ballem PJ, Segal GM, Stratton JR, Gernsheimer T, Adamson JW, Slichter SJ: Mechanisms of thrombocytopenia in chronic autoimmune thrombocytopenic purpura. Evidence of both impaired platelet production and increased platelet clearance. J Clin Invest 1987;80:33-40. 